\title{
Variable rate nitrogen management in corn: Response in two crop rotations
}

\author{
D.W. Barker and J.E. Sawyer
}

\begin{abstract}
Decision-making criteria to accurately predict nitrogen $(\mathrm{N})$ rates in corn (Zea mays L.) would greatly benefit canopy sensor-guided variable rate $\mathrm{N}$ (VRN) management with positive implications for water quality. The objectives of this study were to measure corn yield response toVRN applied at the midvegetative corn growth stage and compare yield and agronomic efficiency (AE) between a one-time spring- $\mathrm{N}$ application (preplant or early sidedress) and two VRN management strategies, split-N $\left(V_{R} N^{S}\right)$ and rescue-N $\left(V_{R} N^{R}\right)$. Field sites located across Iowa received spring-N fertilizer at six application rates, with additional $\mathrm{N}$ potentially applied with each VRN spring-N rate and for the $V R N^{S}$ and VRN ${ }^{\mathrm{R}}$ strategies at the V10 growth stage based on canopy sensing. Drought conditions were evident during 2012 and 2013 in Iowa, which resulted in reduced corn yield and requirement for $\mathrm{N}$ fertilizer at many site-years. The VRN with 0 and $56 \mathrm{~kg} \mathrm{~N} \mathrm{ha}^{-1}\left(50 \mathrm{lb} \mathrm{N} \mathrm{ac}^{-1}\right)$ applied in the spring was most closely aligned with calculated economic optimum $N$ rate and AE. The VRN ${ }^{S}$ and $\mathrm{VRN}^{\mathrm{R}}$ strategies applied more $\mathrm{N}$ than was needed, compared to spring- $\mathrm{N}$ only. Canopy sensors did not detect adequate to excess $\mathrm{N}$, and therefore $\mathrm{N}$ applied prior to VRN application should be part of sensing-based algorithm criteria. Mean corn yield with the soybean (Glycine max [L.] Merr.)-corn rotation was not maintained with VRN when no spring-N was applied. Yield comparison showed no differences between spring-N, VRN ${ }^{\mathrm{S}}$, and $\mathrm{VRN}^{\mathrm{R}}$ for both rotations. However, the greatest $\mathrm{AE}$ was achieved with spring-N and the VRN ${ }^{\mathrm{S}}$ strategy in the soybean-corn rotation. Weather events that occur during and after canopy sensing and VRN application remain an important factor for successful corn yield response to $\mathrm{N}$ rate and timing, and should be considered with canopy sensorVRN. Results from this study provide feedback on how to translate remote sensing data into VRN management.
\end{abstract}

Key words: canopy sensors—corn—drought—variable rate nitrogen

\begin{abstract}
Efforts directed at reducing nitrate-nitrogen $\left(\mathrm{NO}_{3}^{-}-\mathrm{N}\right)$ losses to surface waters in lowa have remained a challenging and complex issue. Science-based strategies for reducing total $\mathrm{N}$ loads to Iowa surface waters and the Mississippi River Basin include in-field $\mathrm{N}$ management, land use, and edge-of-field practices (Randall et al.2008; Lawrence 2014). In-field management that couples optimum $\mathrm{N}$ rates, application timing closer to when corn (Zea mays L.) N uptake is rapid, and use of site-specific zones for $\mathrm{N}$ management has potential to reduce $\mathrm{NO}_{3}{ }^{-}-\mathrm{N}$ losses with no detriment to corn production (Khosla et al. 2002; Scharf et al. 2002; Randall et al. 2008).

Past studies that seek to synchronize $\mathrm{N}$ application with $\mathrm{N}$ uptake in Iowa have provided inconsistent results regarding the agronomic benefit of sidedress and midseason
\end{abstract}

the first application at or near planting, with the second within one month of planting ( $\mathrm{N}$ rate determined by the late spring $\mathrm{NO}_{3}^{-}$test) (Baker et al. 1995). Unpredictable weather after sidedressing involves risk for overall $\mathrm{N}$ management, including in-season $\mathrm{N}$ strategies. Baker et al. (1995) stated that care must be taken not to apply $\mathrm{N}$ too late where $\mathrm{N}$ may be unavailable to corn roots in dry surface soil. Randall et al. (2003) concluded that considerable variation in growing season precipitation and temperature from year to year demonstrates negative effects on $\mathrm{N}$ management strategies from weather-induced $\mathrm{N}$ losses. Some researchers have found that $\mathrm{N}$ applied in-season can simply remain in the soil profile through corn harvest, increasing the potential for $\mathrm{NO}_{3}^{-}-\mathrm{N}$ losses (Killorn et al. 1995; Jaynes and Colvin 2006). Split timing strategies based on the Minolta SPAD meter ( $\mathrm{N}$ applied at the V15 leaf stage through VT tasseling stage) versus a single $\mathrm{N}$ rate at planting resulted in reduced in-season fertilizer $\mathrm{N}$ recovery and lower yield with the split strategy (Ruiz Diaz et al. 2008). A more recent study comparing preplant and preplant plus additional sensor-based $\mathrm{N}$ at midvegetative growth revealed that the optimum rate of fertilizer and recovery of applied $\mathrm{N}$ were the same for both timings (Barker and Sawyer 2012).

In order to more precisely respond to corn $\mathrm{N}$ requirements through VRN management, farmers need tools that are easy to employ in farming operations and consistently improve $\mathrm{N}$ fertilizer use by crops. Currently, two active canopy sensor strategies can be used forVRN fertilizer management. A VRN-split $\left(V_{R N}{ }^{S}\right)$ strategy involves a portion of $\mathrm{N}$ applied in spring and a portion in-season based on canopy sensing, often during midvegetative growth. A VRN-rescue $\left(V_{R}{ }^{R}\right)$ strategy involves all expected $\mathrm{N}$ needs applied in spring with additional $\mathrm{N}$ applied in-season if $\mathrm{N}$ losses occur from excess rainfall or additional corn $\mathrm{N}$ needs become uncertain. For both of these strategies, sensors determine the in-season $\mathrm{N}$ rate. However, research suggests within-field $\mathrm{N}$ management is complex and involves temporal factors that are not well understood (Doerge 2002; Delgado et al. 2005; Fox and Walthall 2008). For example, use of active sensors for VRN

Daniel W. Barker is an assistant scientist III and John E. Sawyer is a professor in the Department of Agronomy at lowa State University in Ames, lowa. 
management require in-field calibration from a nonlimiting $\mathrm{N}$ area or virtual reference, $\mathrm{N}$ rate algorithms appropriate for the corn growing region, and VRN application limitations imposed to ensure reasonable $\mathrm{N}$ application rates. End-users and service providers question a single, widely applicable sensor-algorithm configuration from sensor equipment manufacturers. Also, assessing specific causal agents of crop stress (that is, $\mathrm{N}$ deficiency symptoms versus other stress issues) solely from remotely sensed data is difficult due to numerous forms of crop stress that exhibit similar canopy reflectance (Scharf et al. 2002; Fox and Walthall 2008). However, when VRN management is performed correctly, systems can address spatial and temporal variability of corn $\mathrm{N}$ need within-field up to the time of sensing. Khosla et al. (2002) and Delgado et al. (2005) reported spatially variable $\mathrm{N}$ management based on productivity zones maintained maximum yields (compared to uniform strategies) as well as a $25 \%$ reduction in $\mathrm{NO}_{3}^{-}$leaching losses the year following VRN site-specific management. The USDA NRCS considers precision application technology for applying crop nutrients a water quality enhancement activity under the Conservation Stewardship Program (CSP) (USDA NRCS 2015a).

Research on $\mathrm{N}$ timing strategies with variable rate technologies such as canopy sensors will improve our understanding of potential benefits and pitfalls of in-field $\mathrm{N}$ management in corn. Therefore, this study was conducted to measure corn yield response to VRN applied fertilizer based on canopy sensing during the V10 corn growth stage, and compare yield and $\mathrm{N}$ use efficiency between spring-applied $\mathrm{N}, \mathrm{VRN}^{\mathrm{S}}$, and VRN ${ }^{\mathrm{R}}$ strategies.

\section{Materials and Methods}

Twelve corn field trials were conducted at six Iowa State University Research and Demonstration Farms located within major soil types and landform regions of Iowa (table 1 and figure 1). Corn was planted in 76 $\mathrm{cm}$ (30 in) rows. Plots were six or eight rows wide by $15 \mathrm{~m}$ (50 ft) long. Tillage systems were fall chisel plow and spring disc/field cultivate for site-years with corn-corn (CC) or spring disc/field cultivate for site-years with soybean (Glycine max [L.] Merr.)-corn (SC) rotation. Spring-N rate and VRN treatments were arranged in a completely randomized design with three replications.
The spring-N rates were duplicated, with one set having potential VRN application and the other having no VRN application. The VRN ${ }^{S}$ and VRN ${ }^{R}$ treatments were replicated three times and nested at random within the spring-N rate and VRN treatments (figure 1). Spring-N fertilizer (0 to $280 \mathrm{~kg} \mathrm{~N} \mathrm{ha} a^{-1}\left[250 \mathrm{lb} \mathrm{N} \mathrm{ac}^{-1}\right]$ in $56 \mathrm{~kg}$ [50 lb] increments) was broadcast incorporated urea or subsurface banded urea ammonium nitrate $\left(\mathrm{NH}_{4} \mathrm{NO}_{3}^{-}\right)$solution applied in the spring (preplant or early sidedress) (table 2). For each spring-N rate, VRN applications were broadcast by hand across the corn canopy at the V10 growth stage (Abendroth et al. 2011) using urea treated with the urease inhibitor $\mathrm{N}$-(n-butyl) thiophosphoric acid triamide (NBPT) (USDA NRCS 2015c).

Two VRN strategies were compared with a single base spring-N rate specific for each crop rotation. The $\mathrm{VRN}^{\mathrm{S}}$ strategy was spring-N at $84 \mathrm{~kg} \mathrm{~N} \mathrm{ha}^{-1}\left(75 \mathrm{lb} \mathrm{N} \mathrm{ac}^{-1}\right)$ for $\mathrm{SC}$ or $112 \mathrm{~kg} \mathrm{~N} \mathrm{ha}^{-1}\left(100 \mathrm{lb} \mathrm{N} \mathrm{ac}^{-1}\right)$ for CC, and with theVRN ${ }^{\mathrm{S}}$ having a minimum application rate of not less than $84 \mathrm{~kg} \mathrm{~N} \mathrm{ha}^{-1}$ for $\mathrm{SC}$ or $112 \mathrm{~kg} \mathrm{~N} \mathrm{ha}^{-1}$ for CC, with no maximum rate. The VRN ${ }^{\mathrm{R}}$ strategy was spring-N at $168 \mathrm{~kg} \mathrm{~N} \mathrm{ha}^{-1}\left(150 \mathrm{lb} \mathrm{N} \mathrm{ac}^{-1}\right)$ for SC or $224 \mathrm{~kg} \mathrm{~N} \mathrm{ha}^{-1}$ (200 lb N ac${ }^{-1}$ ) for CC, with the VRN having no minimum or maximum application rate. The spring- $\mathrm{N}$ rates selected for the VRN ${ }^{\mathrm{R}}$ strategy in each crop rotation were determined using the upper range of the most profitable $\mathrm{N}$ rate from the Corn $\mathrm{N}$ Rate Calculator for Iowa (Sawyer et al. 2006; ISU Agronomy Extension 2012).

The active canopy sensor used was the Crop Circle ACS-210 (Holland Scientific, Lincoln, Nebraska). A single sensor unit was mounted on a handheld mast and carried at $\left.1.3 \mathrm{~m} \mathrm{~s}^{-1}(0.4 \mathrm{ft} \mathrm{sec})^{-1}\right)$ through the middle of each plot (positioned midrow, sensing two corn rows). The sensor emits light at the $590 \mathrm{~nm}$ and $880 \mathrm{~nm}$ wavelengths. The mean visible and infrared reflectance variables were calculated for each plot and used to calculate normalized difference vegetative index (NDVI). The VRN applied at the V10 growth stage was determined using a relative NDVI algorithm tested in Iowa by Barker and Sawyer (2010). The $\mathrm{N}$ reference was the highest mean NDVI value from a plot at each site (regardless of applied spring- $\mathrm{N}$ rate). The intent was to mimic a production applicator that utilizes a virtual reference by recording and utilizing the highest NDVI as the applicator travels through the field (Holland and
Schepers 2013). Corn was harvested with a plot combine and adjusted to $15.5 \%$ moisture content. The agronomic efficiency (AE) for VRN, spring-N, VRN ${ }^{\mathrm{S}}$, and $\mathrm{VRN}^{\mathrm{R}}$ comparison was calculated as $\mathrm{AE}=($ fertilized $\mathrm{N}$ yield - zero N yield) $\div$ total N applied (IPNI 2013).

Statistical Analysis. Corn yield response to spring-N rate was determined for each site-year with PROC GLM (SAS Institute 2010). Site-years were deemed nonresponsive to $\mathrm{N}$ fertilizer application if $\mathrm{N}$ rate was not significant $(p \leq 0.10)$ (three site-years were nonresponsive to fertilizer $\mathrm{N}$; table 2). The PROC NLIN procedure was used to fit quadratic or quadratic-plateau regression models for each site-year identified as responsive, and quadratic-plateau to the across site-year mean spring- $\mathrm{N}$ rate response. The fitted regression models were used to determine economic optimum $\mathrm{N}$ rate (EONR) for each site-year using the ratio of fertilizer cost, US\$0.66 kg-1 N (US\$0.30 lb $\left.\mathrm{kg}^{-1} \mathrm{~N}\right)$, and corn grain price, US\$0.12 $\mathrm{kg} \mathrm{N}^{-1}$ (US $\$ 3.00$ $\mathrm{bu}^{-1}$ grain), or the site-year EONR was set to zero if the site was not $\mathrm{N}$ responsive. For the across site-year mean in SC:

$$
\begin{aligned}
& \text { 1. } y=7,149+39.76 x-0.1105 x^{2} \text { if } x \leq 180 \\
& \mathrm{~kg} \mathrm{~N} \mathrm{ha}^{-1}\left(y=114+0.71 x-0.00221 x^{2}\right. \\
& \text { if } \left.x \leq 161 \mathrm{lb} \mathrm{N} \mathrm{ac}^{-1}\right), \\
& \text { 2. } y=10,723 \mathrm{~kg} \mathrm{ha}^{-1} \text { if } x>180 \mathrm{~kg} \mathrm{~N} \mathrm{ha}^{-1} \\
& \left(y=171 \mathrm{bu} \mathrm{ac}^{-1} \text { if } x>161 \mathrm{lb} \mathrm{N} \mathrm{ac}^{-1}\right), \\
& \text { 3. } R^{2}=0.99, \\
& \text { 4. } p<0.001, \text { and } \\
& \text { 5. } \text { mean EONR }=155 \mathrm{~kg} \mathrm{~N} \mathrm{ha}^{-1}(138 \mathrm{lb} \\
& \mathrm{N} \mathrm{ac}) \text {. }
\end{aligned}
$$

For the across site-year mean in CC:

1. $y=3,512+29.68 x-0.0775 x^{2}$ if $x \leq 192$

$\mathrm{kg} \mathrm{N} \mathrm{ha}{ }^{-1}\left(y=56+0.53 x-0.00155 x^{2}\right.$ if $\left.x \leq 171 \mathrm{lb} \mathrm{N} \mathrm{ac}^{-1}\right)$,

2. $y=6,396 \mathrm{~kg} \mathrm{ha}^{-1}$ if $x>192 \mathrm{~kg} \mathrm{~N} \mathrm{ha}^{-1}$ $\left(y=102 \mathrm{bu} \mathrm{ac}^{-1}\right.$ if $\left.x>171 \mathrm{lb} \mathrm{N} \mathrm{ac}^{-1}\right)$,

3. $R^{2}=0.94$

4. $p=0.015$, and

5. mean EONR $=156 \mathrm{~kg} \mathrm{~N} \mathrm{ha}^{-1}(139 \mathrm{lb}$ $\left.\mathrm{N} \mathrm{ac}^{-1}\right)$.

Grain yield and AE were statistically analyzed across site-year using PROC GLIMMIX for VRN effects (tables 5 and 6) and $N$ strategy effects (table 7). Site-years and replicates were considered random. The LINES option was used to determine $\mathrm{N}$ rate differences $(p \leq 0.10)$.

\section{Results and Discussion}

Effects of Drought on Corn Production. Corn growth and development were significantly 
Table 1

Soil characterization and soil test levels at each site-year.

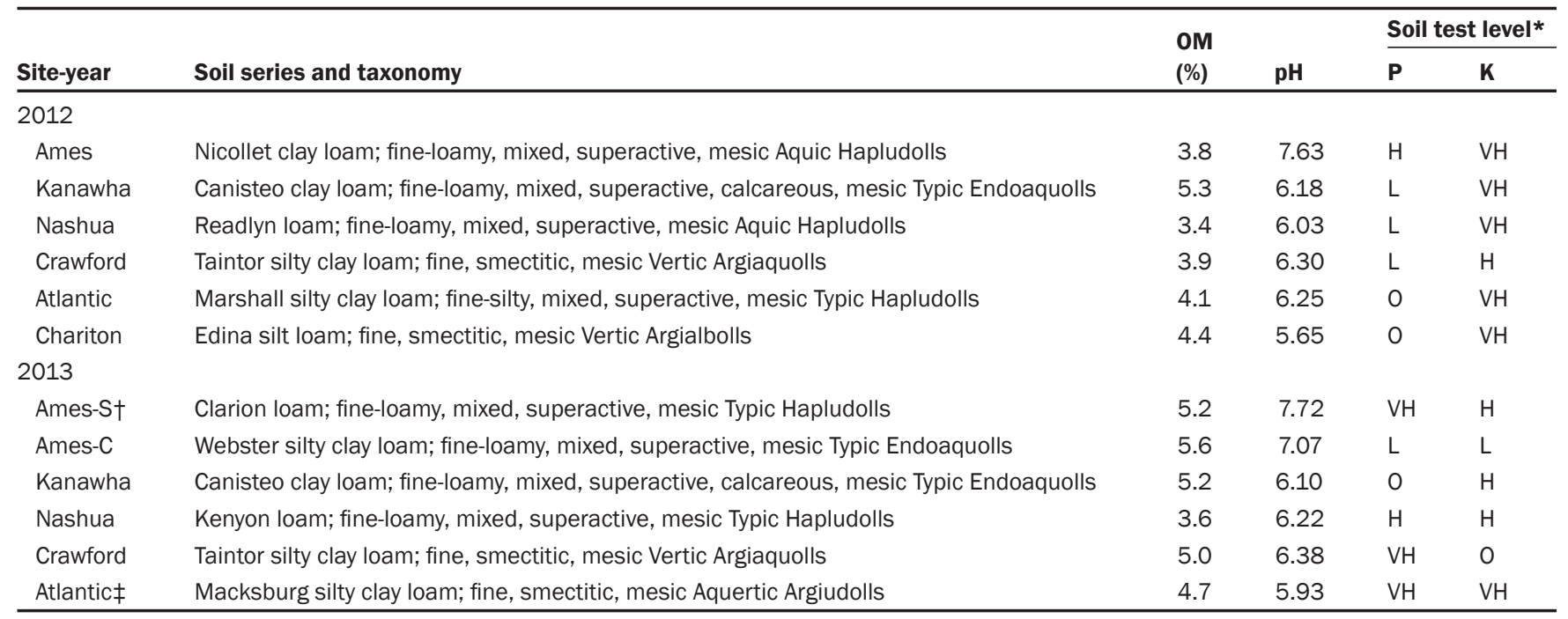

Notes: $\mathrm{OM}=$ organic matter. $\mathrm{P}=$ phosphorus. $\mathrm{K}=$ potassium. $\mathrm{L}=$ low. $\mathrm{O}=$ optimum. $\mathrm{H}=$ high. $\mathrm{VH}=$ very high.

*Soil test interpretation categories for 0 to 6 in soil depth samples according to Mallarino et al. (2013).

†Fall of 2012, $10 \mathrm{lb} \mathrm{N} \mathrm{ac}^{-1}$ as monoammonium phosphate with sulfur (S) and zinc (Zn) applied across site.

¥Fall of 2012, $37 \mathrm{lb} \mathrm{N} \mathrm{ac}^{-1}$ as monoammonium phosphate applied across site.

\section{Figure 1}

Example study design schematic and lowa map depicting the lowa State University Research and Demonstration Farms across the landform regions of lowa. VRN ${ }^{S}$ signifies a variable rate nitrogen $(\mathrm{N})$-split strategy, and VRN ${ }^{R}$ signifies a VRN-rescue strategy.

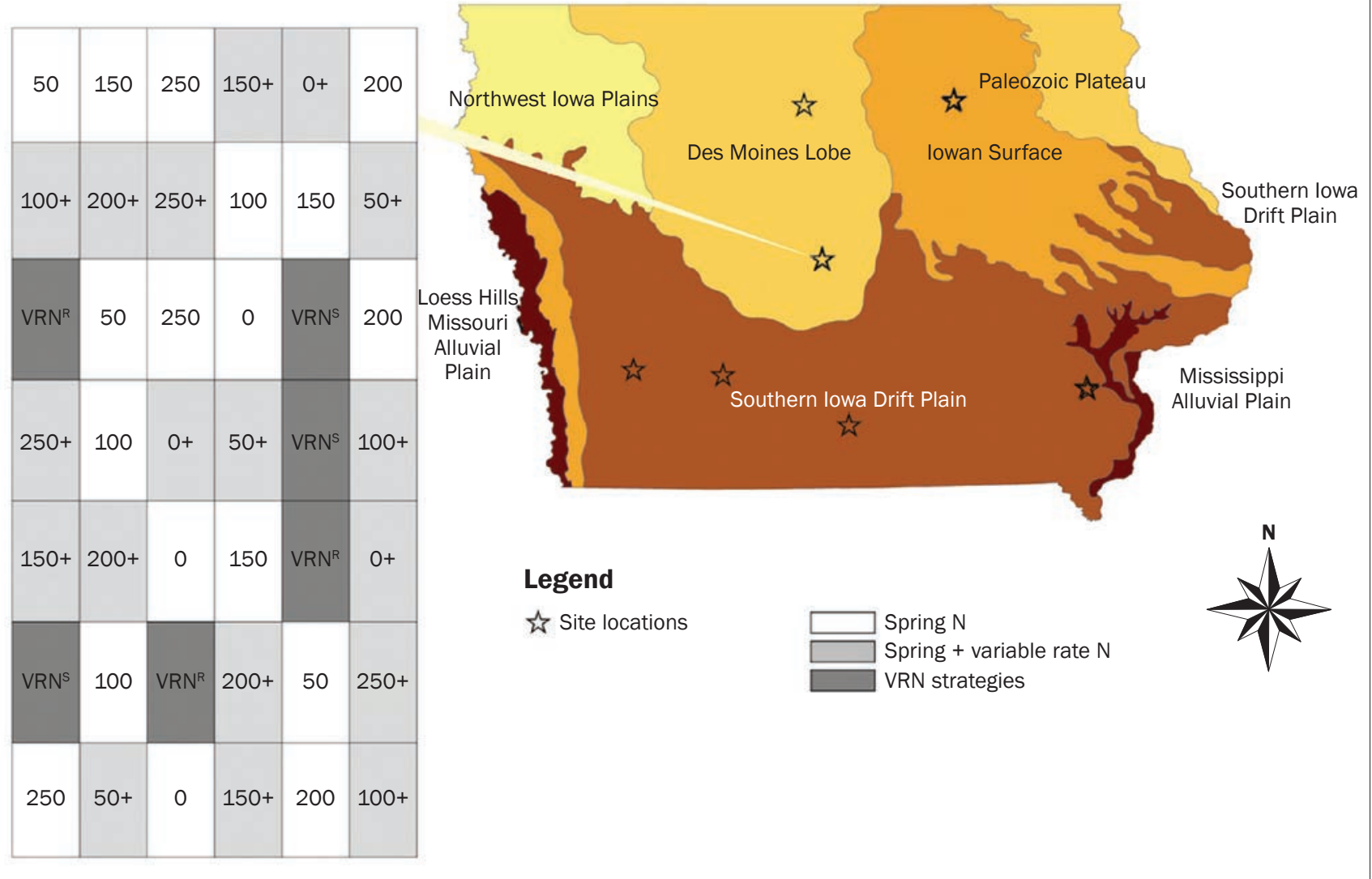




\section{Table 2}

Agronomic information and dates of spring-nitrogen $(\mathrm{N})$ and variable rate nitrogen (VRN) applications at each site-year.

\begin{tabular}{lllllll}
\hline & & & \multicolumn{2}{l}{ Corn planting } & \\
Site-year & $\begin{array}{l}\text { Crop } \\
\text { rotation }\end{array}$ & $\begin{array}{l}\text { Date of } \\
\text { spring-N }\end{array}$ & Date & Hybrid & $\begin{array}{l}\text { CRM } \\
\text { (day) }\end{array}$ & $\begin{array}{l}\text { Date of } \\
\text { VRN }\end{array}$ \\
\hline 2012 & & & & & & \\
Ames* & CC & May 10 & April 12 & DKC 62-97 & 112 & June 25 \\
Kanawha & SC & April 4 & May 10 & P 0448XR & 104 & June 26 \\
Nashua* & SC & April 3 & May 10 & DKC 55-09 & 105 & July 5 \\
Crawford & SC & May 11 & May 10 & P 0528AM & 105 & July 1 \\
Atlantic & CC & May 14 & April 25 & DKC 63-42 & 113 & June 28 \\
Chariton & CC & June 13 & May 15 & P 0135AM & 113 & July 3 \\
2013 & & & & & & \\
Ames-S & SC & June 13 & June 1 & A 6225 & 112 & July 15 \\
Ames-C & CC & June 3 & May 16 & DKC 62-54 & 112 & July 11 \\
Kanawha & SC & April 29 & May 13 & P 36V51 & 102 & July 5 \\
Nashua & SC & May 1 & May 15 & P 0297XR & 102 & July 5 \\
Crawford & SC & June 5 & May 15 & DKC 61-89 & 111 & July 8 \\
Atlantic* & SC & June 12 & May 16 & P 1151AM & 111 & July 10 \\
\hline
\end{tabular}

Notes: $\mathrm{SC}=$ corn following soybean. $\mathrm{CC}=$ continuous corn. $\mathrm{P}=$ DuPont Pioneer. $\mathrm{DKC}=$ Dekalb. $\mathrm{A}=$ Agrigold hybrids. $\mathrm{CRM}=$ corn relative maturity. Seeding rate at all sites was approximately 35,000 seeds $\mathrm{ac}^{-1}$.

*Nonresponsive site-years to spring-N fertilizer.

affected by summer drought conditions during the 2012 and 2013 growing seasons (table 3 ). In the period from April 2 to July 16 in 2012, the US Drought Monitor categories abnormally dry (D0), moderately dry (D1), and severe drought (D2) were present in four out of five Iowa counties where siteyears were located. From July 24 to August 21 (period after VRN application in 2012), D2 or extreme drought (D3) was present in all site-year counties. In 2013, drought conditions were still present but much more variable than in 2012. The Kanawha 2013 site-year county experienced the most drought conditions (D0 to D3 categories) during the period from April 2 to July 16. In other counties where site-years were located, there were approximately half the counties with no drought or in the D0 through D2 categories. Notably, the Crawford 2013 site-year county had essentially no drought during the April 2 to July 16 timeframe. In summer after VRN application (July 24 to August 21), Nashua 2013 site-year had no drought and a majority of the county was in the D0 category at Crawford and Kanawha 2013. Lastly, the counties for Ames-S, Ames-C, and Atlantic 2013 experienced the driest conditions with drought categories at the D0 to D1 levels. Overall, the VRN period in 2013 endured significantly less drought compared to 2012. Climate patterns (that produce low soil moisture and reduced plant water uptake) are closely linked to the $\mathrm{N}$ cycle, driving rate of $\mathrm{N}$ mineralization, denitrification, and $\mathrm{N}$ fertilizer use (Randall et al. 2008). In this study, dry soil conditions contributed in part to three site-years being nonresponsive to spring-N applied fertilizer (Ames and Nashua 2012 and Atlantic 2013), as well as reduced corn growth and development for site-years in the CC rotation (Ames 2012 and 2013 and Chariton 2012).

Variable Rate Nitrogen Applied at the V10 Growth Stage. The VRN rates in table 4 were applied during the V10 growth stage with the different spring- $\mathrm{N}$ fertilizer rates (0 to $280 \mathrm{~kg} \mathrm{~N} \mathrm{ha}{ }^{-1}$ [0 to $250 \mathrm{lb} \mathrm{N} \mathrm{ac}^{-1}$ ]) and for $\mathrm{VRN}^{\mathrm{S}}$ and $\mathrm{VRN}^{\mathrm{R}}$ strategies. The VRN application rate was influenced by spring-N rate; moreover, when less spring-N was applied, the more VRN was recommended. This trend also remained consistent when comparing the $\mathrm{VRN}^{\mathrm{S}}$ (decreased base spring-N rate equating to more VRN) and $V_{R} N^{R}$ (increased base spring- $\mathrm{N}$ rate equating to less VRN) strategies. The SC rotation had less VRN recommended when compared to CC. However, when compared to the calculated EONR with spring application, 154 and $155 \mathrm{~kg} \mathrm{~N} \mathrm{ha}^{-1}$ (138 and 139 lb $\mathrm{N} \mathrm{ac}^{-1}$ ) for SC and CC, respectively, there was surplus VRN applied in both rotations. At the Kanawha 2012, Nashua 2012,
Crawford 2012 and 2013, and Atlantic 2013 site-years, the $\mathrm{VRN}^{\mathrm{S}}$ applied the least amount of $\mathrm{N}\left(\leq 5.6 \mathrm{~kg} \mathrm{~N}^{-1}\left[5 \mathrm{lb} \mathrm{N} \mathrm{ac}^{-1}\right]\right)$ beyond the spring base $\mathrm{VRN}^{\mathrm{S}}$ strategy application level (84 kg N ha-1 [75 lb N ac${ }^{-1}$ ] for $\mathrm{SC})$. The $\mathrm{VRN}^{\mathrm{R}}$ with the spring base $168 \mathrm{~kg}$ $\mathrm{N} \mathrm{ha}^{-1}$ (150 lb N ac ${ }^{-1}$; SC site-years) and 224 $\mathrm{kg} \mathrm{N} \mathrm{ha}^{-1}$ (200 lb N ac${ }^{-1}$; CC site-years) rates applied excessive $\mathrm{N}$ at $\mathrm{V} 10$.

The applied VRN combined with spring- $\mathrm{N}$ rates were meant to target a season-long optimum $\mathrm{N}$ rate for a given site-year and crop rotation. Water stress can increase visible (VIS) and near-infrared (NIR) reflectance, and some reflectance indexes can be sensitive to physiological changes related to moisture stress in the plant. Major N deficiencies are easier to detect and quantify than minor $\mathrm{N}$ deficiencies; however, high corn leaf chlorophyll saturates reflectance values between $80 \%$ and $100 \%$ of recommended $\mathrm{N}$ levels (Fox and Walthall 2008). When no apparent $\mathrm{N}$ stress symptoms were present at theV10 corn growth stage across the site-years studied, the canopy sensor system applied too much VRN-a potential result of the issues mentioned above. In addition, use of the intended virtual reference approach of using the plots with the highest NDVI may have added to additional VRN fertilizer. Further research would be helpful to determine the most effective sensor referencing method. Virtual referencing does provide improved field spatial determination of adequate plant $\mathrm{N}$ areas, compared to fertilized reference areas. Virtual referencing also provides end-users a simpler method for referencing the sensor system.

Grain Yield Response to Variable Rate Nitrogen. The VRN effects on grain yield by site-year and crop rotation are presented in table 5. Statistically significant yield increase with VRN addition across spring- $\mathrm{N}$ rates occurred at Crawford 2012, Atlantic 2012, and Nashua 2013. This indicates the VRN rate with deficit spring- $\mathrm{N}$ (spring- $\mathrm{N}$ rates below the site EONR, especially the 0 and $56 \mathrm{~kg} \mathrm{~N} \mathrm{ha}^{-1}\left[50 \mathrm{lb} \mathrm{N} \mathrm{ac}^{-1}\right.$ ] rates) at these site-years was not fully utilized by corn when applied at the V10 growth stage, or did not fully recover from $\mathrm{N}$ deficiency. Sites that were nonresponsive with spring- $\mathrm{N}$ had VRN applied with all spring-N rates (table 4 ), but experienced no yield increase. At the other six site-years, there were no yield differences with VRN across spring-N rates, 
Table 3

Characterization of drought in lowa counties during the period of corn planting and nitrogen $(\mathrm{N})$ fertilizer application, and the period after variable rate nitrogen (VRN) application, US Drought Monitor (USDM) categories.

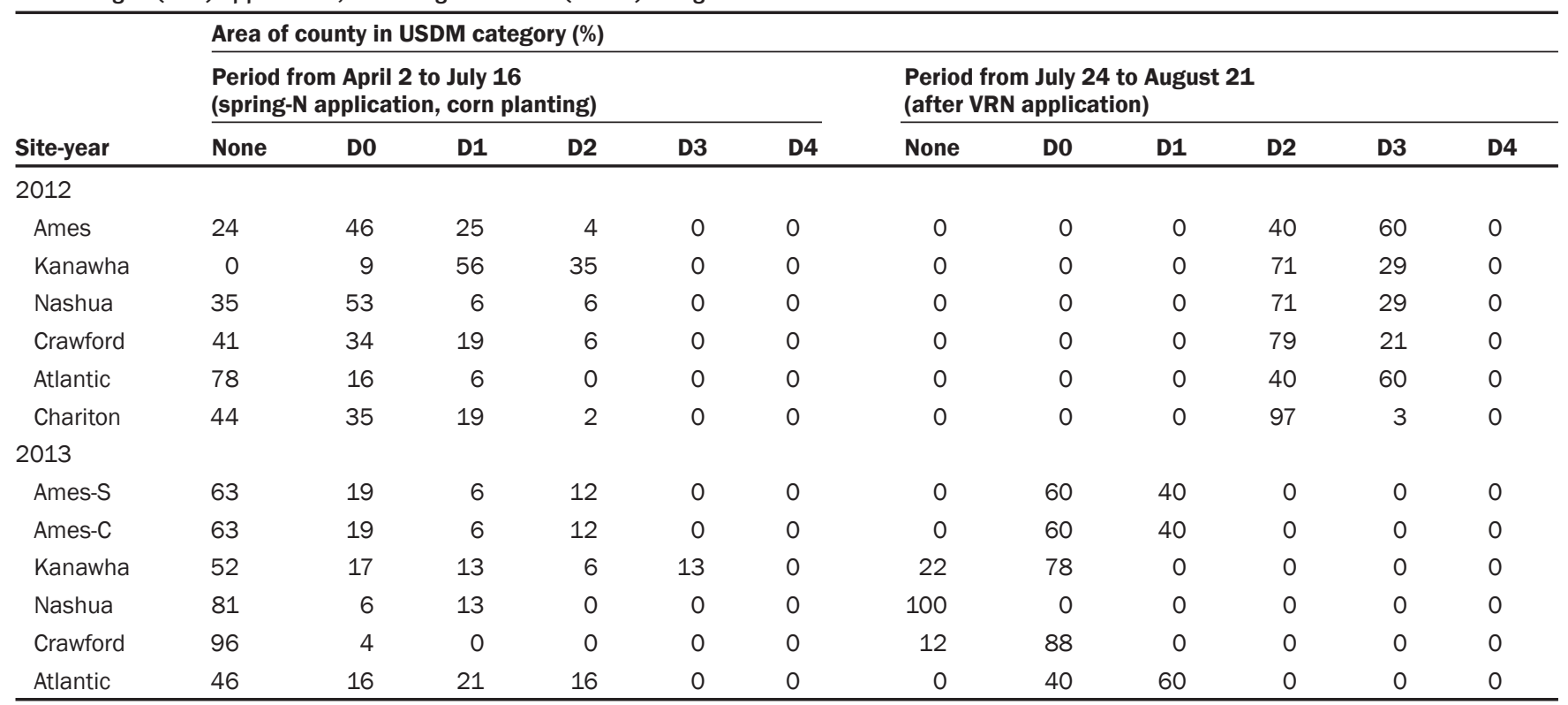

Notes: None = no drought. D0 = abnormally dry. D1 = moderate drought. D2 = severe drought. D3 = extreme drought. D4 = exceptional drought.

indicating the crop utilized VRN when applied at the V10 growth stage.

The yield response to VRN in the SC rotation revealed that at the zero spring $\mathrm{N}$ rate, VRN application did not adequately recover yield losses due to $\mathrm{N}$ deficiency that occurred prior to the $\mathrm{V} 10$ growth stage. However, corn yield at the 56 and $112 \mathrm{~kg} \mathrm{~N}$ $\mathrm{ha}^{-1}$ (50 and $100 \mathrm{lb} \mathrm{N} \mathrm{ac}{ }^{-1}$ ) spring-N with VRN (SC rotation) were nearly equal to the calculated $10,723 \mathrm{~kg} \mathrm{ha}^{-1}\left(171 \mathrm{bu} \mathrm{ac}^{-1}\right.$ ) EONR yield. The mean grain yield in CC was significantly lower compared to SC. In contrast to SC,VRN applied in CC with the zero spring- $\mathrm{N}$ rates resulted in yield equal to all other combinations of spring- $\mathrm{N}$ and VRN. The VRN rate at the zero spring-N rate of $232 \mathrm{~kg} \mathrm{~N} \mathrm{ha}^{-1}\left(207 \mathrm{lb} \mathrm{N} \mathrm{ac}^{-1}\right)$ was well above the mean CC EONR $(76 \mathrm{~kg} \mathrm{~N}$ $\mathrm{ha}^{-1}$ [68 $\mathrm{lb} \mathrm{N} \mathrm{ac}^{-1}$ ] greater). Although there were no significant VRN differences across spring- $\mathrm{N}$ rates (indicating response to the VRN), corn yield potential and demand for applied $\mathrm{N}$ was low in CC. The calculated EONR yield for CC was $6,396 \mathrm{~kg} \mathrm{ha}^{-1}$ $\left(102 \mathrm{bu} \mathrm{ac}^{-1}\right)$, compared to $5,268,5,644$, and $6,020 \mathrm{~kg} \mathrm{ha}^{-1}\left(84,90\right.$, and $\left.96 \mathrm{bu} \mathrm{ac}^{-1}\right)$ from the spring-N plus VRN at 0,56 , and $112 \mathrm{~kg}$ $\mathrm{N} \mathrm{ha}^{-1}\left(0,50\right.$, and $\left.100 \mathrm{lb} \mathrm{N} \mathrm{ac}^{-1}\right)$, respectively. In general, there was yield response to VRN at spring- $\mathrm{N}$ rates below the mean optimum, but those yield increases came at an expense of higher (spring-N plus VRN) $\mathrm{N}$ applica-

Table 4

Variable rate nitrogen (VRN) applied at V10 using a canopy sensor, by site-year and crop rotation.

\begin{tabular}{|c|c|c|c|c|c|c|c|c|}
\hline \multirow[b]{2}{*}{ Site-year } & \multicolumn{6}{|c|}{ Mean VRN (Ib N ac ${ }^{-1}$ ) } & \multirow[b]{2}{*}{ VRN $^{\mathbf{S}}$} & \multirow[b]{2}{*}{ VRN $^{R}$} \\
\hline & $0+$ & $50+$ & $100+$ & $150+$ & $200+$ & $250+$ & & \\
\hline \multicolumn{9}{|l|}{2012} \\
\hline Ames & 218 & 110 & 100 & 63 & 28 & 77 & 115 & 62 \\
\hline Kanawha & 112 & 73 & 65 & 58 & 55 & 45 & 75 & 57 \\
\hline Nashua & 125 & 93 & 82 & 78 & 75 & 77 & 78 & 55 \\
\hline Crawford & 148 & 87 & 97 & 60 & 30 & 28 & 80 & 57 \\
\hline Atlantic & 212 & 137 & 132 & 98 & 78 & 102 & 123 & 52 \\
\hline Chariton & 240 & 155 & 117 & 93 & 117 & 92 & 121 & 118 \\
\hline \multicolumn{9}{|l|}{2013} \\
\hline Ames-S & 177 & 119 & 123 & 150 & 136 & 143 & 137 & 64 \\
\hline Ames-C & 159 & 228 & 137 & 117 & 119 & 109 & 145 & 103 \\
\hline Kanawha & 253 & 162 & 72 & 81 & 85 & 52 & 126 & 80 \\
\hline Nashua & 270 & 207 & 143 & 122 & 52 & 92 & 153 & 104 \\
\hline Crawford & 177 & 87 & 27 & 65 & 72 & 27 & 75 & 74 \\
\hline Atlantic & 80 & 83 & 83 & 79 & 74 & 76 & 77 & 67 \\
\hline \multicolumn{9}{|c|}{ Crop Rotation } \\
\hline Mean SC & 168 & 114 & 87 & 87 & 73 & 67 & 100 & 70 \\
\hline Mean CC & 207 & 158 & 121 & 93 & 86 & 95 & 126 & 84 \\
\hline
\end{tabular}

Notes: $\mathrm{SC}=$ corn after soybean. $\mathrm{CC}=$ continuous corn. $\mathrm{VRN}^{\mathrm{S}}=$ variable rate $\mathrm{N}$-split strategy. $\mathrm{VRN}^{\mathrm{R}}=$ variable rate $\mathrm{N}$-rescue strategy. Across site-year mean $\mathrm{SC}$ economic optimum $\mathrm{N}$ rate $=$ $138 \mathrm{lb} \mathrm{N} \mathrm{ac}^{-1}$ and $\mathrm{CC}=139 \mathrm{lb} \mathrm{N} \mathrm{ac}^{-1}$.

tions. This indicates low efficiency of VRN use during this study.

Agronomic Efficiency Response to Variable Rate Nitrogen. The VRN effects on AE by site-year and crop rotation are presented in table 6. The Crawford 2012 and 2013 and Nashua 2013 sites had the highest AE, with those site-years also showing an AE increase with VRN in addition to the low spring-N rates. For two of those site-years (Crawford 
Table 5

Effects of variable rate nitrogen (VRN) (spring + VRN) management using a canopy sensor on grain yield, by site-year and crop rotation.

\begin{tabular}{|c|c|c|c|c|c|c|c|}
\hline \multirow[b]{2}{*}{ Site-year } & \multicolumn{6}{|c|}{ Grain yield (bu ac ${ }^{-1}$ ) } & \multirow{2}{*}{$\begin{array}{l}\text { Statistics } \\
(P>F)\end{array}$} \\
\hline & $0+$ & $50+$ & $100+$ & $150+$ & $200+$ & $250+$ & \\
\hline \multicolumn{8}{|l|}{2012} \\
\hline Ames & 123 & 117 & 118 & 115 & 129 & 113 & 0.991 \\
\hline Kanawha & 135 & 143 & 130 & 146 & 135 & 128 & 0.642 \\
\hline Nashua & 158 & 179 & 174 & 165 & 167 & 160 & 0.532 \\
\hline Crawford & $112 c$ & $147 b$ & $160 \mathrm{ba}$ & $154 b$ & $172 a$ & $169 a$ & $<0.001$ \\
\hline Atlantic & $74 b$ & $89 \mathrm{ba}$ & $102 a$ & $103 a$ & $106 a$ & $105 a$ & 0.060 \\
\hline Chariton & 83 & 77 & 81 & 81 & 99 & 87 & 0.419 \\
\hline \multicolumn{8}{|l|}{2013} \\
\hline Ames-S & 169 & 176 & 188 & 176 & 179 & 171 & 0.302 \\
\hline Ames-C & 57 & 77 & 84 & 95 & 97 & 104 & 0.495 \\
\hline Kanawha & 168 & 169 & 192 & 186 & 193 & 203 & 0.253 \\
\hline Nashua & $200 e$ & $216 d$ & $223 d c$ & $235 b a$ & $243 a$ & $230 \mathrm{bc}$ & $<0.001$ \\
\hline Crawford & 119 & 141 & 130 & 139 & 134 & 139 & 0.554 \\
\hline Atlantic & 155 & 170 & 164 & 157 & 167 & 164 & 0.804 \\
\hline \multicolumn{8}{|l|}{ Crop rotation } \\
\hline Mean SC & $152 b$ & $168 a$ & $170 a$ & $170 a$ & $174 a$ & $170 a$ & $<0.001$ \\
\hline Mean CC & 84 & 90 & 96 & 99 & 102 & 108 & 0.147 \\
\hline
\end{tabular}

Notes: SC = corn after soybean. $\mathrm{CC}=$ continuous corn. Across site-year mean SC grain yield at the spring- $\mathrm{N}$ economic optimum $\mathrm{N}$ rate $=171 \mathrm{bu} \mathrm{ac}^{-1}$ and $\mathrm{CC}=102 \mathrm{bu} \mathrm{ac}^{-1}$. Letters indicate significant differences within a row at the $p \leq 0.10$ level.

\section{Table 6}

Effects of variable rate nitrogen (VRN) (spring + VRN) management using a canopy sensor on agronomic efficiency (AE), by site-year and crop rotation.

\begin{tabular}{|c|c|c|c|c|c|c|c|}
\hline \multirow[b]{2}{*}{ Site-year } & \multicolumn{6}{|c|}{$A E\left(b u I^{\prime b ~ N^{-1}}\right)$} & \multirow{2}{*}{$\begin{array}{l}\text { Statistics } \\
(P>F)\end{array}$} \\
\hline & $0+$ & $50+$ & $100+$ & $150+$ & $200+$ & $250+$ & \\
\hline \multicolumn{8}{|l|}{2012} \\
\hline Ames & 0.16 & 0.22 & 0.17 & 0.11 & 0.19 & 0.07 & 0.912 \\
\hline Kanawha & 0.19 & 0.23 & 0.09 & 0.15 & 0.08 & 0.04 & 0.208 \\
\hline Nashua & 0.09 & 0.23 & 0.15 & 0.09 & 0.08 & 0.04 & 0.172 \\
\hline Crawford & $0.28 \mathrm{c}$ & $0.58 a$ & $0.45 b$ & $0.40 b$ & $0.44 b$ & $0.35 b c$ & 0.010 \\
\hline Atlantic & 0.07 & 0.16 & 0.19 & 0.18 & 0.17 & 0.13 & 0.171 \\
\hline Chariton & 0.22 & 0.30 & 0.25 & 0.22 & 0.23 & 0.18 & 0.754 \\
\hline \multicolumn{8}{|l|}{2013} \\
\hline Ames-S & 0.20 & 0.47 & 0.27 & 0.15 & 0.14 & 0.10 & 0.374 \\
\hline Ames-C & 0.09 & 0.11 & 0.20 & 0.20 & 0.17 & 0.16 & 0.859 \\
\hline Kanawha & 0.26 & 0.32 & 0.55 & 0.36 & 0.31 & 0.34 & 0.352 \\
\hline Nashua & $0.37 c$ & $0.45 b c$ & $0.51 \mathrm{ba}$ & $0.50 \mathrm{ba}$ & $0.58 a$ & $0.39 c$ & 0.013 \\
\hline Crawford & $0.18 \mathrm{c}$ & $0.40 a$ & $0.34 \mathrm{ba}$ & $0.23 b c$ & $0.17 c$ & $0.18 c$ & 0.053 \\
\hline Atlantic & 0.39 & 0.23 & 0.11 & 0.06 & 0.08 & 0.06 & 0.611 \\
\hline \multicolumn{8}{|l|}{ Crop rotation } \\
\hline Mean SC & $0.25 b c$ & $0.36 a$ & $0.31 \mathrm{ba}$ & $0.24 b c$ & $0.23 c$ & $0.19 c$ & 0.001 \\
\hline Mean CC & 0.14 & 0.20 & 0.20 & 0.18 & 0.19 & 0.14 & 0.562 \\
\hline
\end{tabular}

Notes: $\mathrm{SC}=$ corn after soybean. $\mathrm{CC}=$ continuous corn. Across site-year mean $\mathrm{AE}$ for $\mathrm{SC}$ at the spring-N economic optimum $\mathrm{N}$ rate $=0.42 \mathrm{bu} \mathrm{lb} \mathrm{N}^{-1}$ and $\mathrm{CC}=0.33 \mathrm{bu} \mathrm{lb} \mathrm{N}^{-1}$. Letters indicate significant differences within a row at the $p \leq 0.10$ level.

2012 and Nashua 2013), this follows the grain yield response, but not for the Atlantic 2012 site-year. All other site-years had very low AE values with the VRN applications. Even with no spring-N, the AE was low for the VRN application. This indicates low $\mathrm{N}$ use efficiency with the VRN applications. Interestingly, the Nashua 2013 site-year had significantly higherVRN application, as well as a significantly higher grain yield compared to other site-years in the SC rotation.

Like yield response, the AE was significantly lower for the VRN applied in the SC rotation when no spring-N was applied. Also, the highest mean AE was with the 56 and $112 \mathrm{~kg} \mathrm{~N} \mathrm{ha}^{-1}$ (50 and $100 \mathrm{lb} \mathrm{N} \mathrm{ac}{ }^{-1}$ ) spring-N plus VRN application, and then AE decreased at higher $\mathrm{N}$ rates. In contrast, the AE for the mean SC EONR was $23.5 \mathrm{~kg}$ corn $\mathrm{kg} \mathrm{N}^{-1}\left(0.42\right.$ bu corn $\left.\mathrm{lb} \mathrm{N}^{-1}\right)$ with all $\mathrm{N}$ applied in spring, greater than any spring- $\mathrm{N}$ plusVRN application. There were no significant differences in $\mathrm{AE}$ across $\mathrm{N}$ rates for $\mathrm{CC}$, the same as the yield response. The AE values in CC were all quite low (significantly lower compared to SC), representing low efficiency of $\mathrm{N}$ use with the VRN management. The AE for the mean CC EONR was $18.5 \mathrm{~kg}$ corn $\mathrm{kg} \mathrm{N}^{-1}$ (0.33 bu corn $\left.\mathrm{lb} \mathrm{N}^{-1}\right)$, greater than any spring-N plus VRN application. The low AE would also be a reflection of the low CC yields in the dry growing conditions. Agronomic efficiency can provide insights into effects of $\mathrm{N}$ timing on corn $\mathrm{N}$ use. Greatest AE is achieved through the lowest $\mathrm{N}$ fertilizer inputs coupled with the highest corn yield (Khosla et al. 2002). In our study, the highest AE was achieved with the spring-N application. Stress effects on canopy reflectance as detected by canopy sensors are only evident after chronic plant stress has occurred (Fox and Walthall 2008). Remote sensing for $\mathrm{N}$ management like all farming operations is susceptible to weather conditions (Scharf et al. 2002), which was the situation in this study related to the dry growing season conditions.

Spring-Nitrogen and Variable Rate Nitrogen Strategy Comparison. The effects of spring-N and the two VRN strategies $\left(V_{R} N^{S}\right.$ and $\left.V R N^{R}\right)$ on grain yield and AE were made between site-years and crop rotation (table 7). The spring-N rates used for comparison (representative of recommended farmer applied rates) were $168 \mathrm{~kg} \mathrm{~N} \mathrm{ha}^{-1}$ $\left(150 \mathrm{lb} \mathrm{N} \mathrm{ac}^{-1}\right)$ in SC and $224 \mathrm{~kg} \mathrm{~N} \mathrm{ha}^{-1}(200$ $\mathrm{lb} \mathrm{N} \mathrm{ac}{ }^{-1}$ ) in CC. The spring- $\mathrm{N}$ base rate for 
Table 7

Comparison of corn grain yield and agronomic efficiency (AE) from spring-nitrogen (N), a variable rate $\mathrm{N}$-split (VRN ${ }^{\mathrm{s}}$ ) strategy, and a VRN-rescue strategy $\left(\mathrm{VRN}^{\mathrm{R}}\right)$, by site-year and crop rotation.

\begin{tabular}{|c|c|c|c|c|c|c|c|c|}
\hline \multirow[b]{2}{*}{ Site-year } & \multicolumn{3}{|c|}{ Grain yield (bu ac ${ }^{-1}$ ) } & \multicolumn{3}{|c|}{ AE (bu lb N-1) } & \multicolumn{2}{|c|}{ Statistics $(P>F)$} \\
\hline & Spring $\mathbf{N}$ & VRN $^{\mathbf{S}}$ & VRN $^{R}$ & Spring $\mathbf{N}$ & VRN $^{S}$ & VRN $^{R}$ & Grain yield & $\mathbf{A E}$ \\
\hline \multicolumn{9}{|l|}{2012} \\
\hline Kanawha & 141 & 143 & 144 & 0.17 & 0.19 & 0.14 & 0.954 & 0.720 \\
\hline Nashua & 159 & 177 & 171 & 0.08 & 0.19 & 0.12 & 0.219 & 0.242 \\
\hline Crawford & 149 & 160 & 171 & 0.52 & 0.58 & 0.49 & 0.205 & 0.573 \\
\hline Chariton & 72 & 96 & 85 & $0.21 b$ & $0.31 a$ & $0.18 b$ & 0.128 & 0.063 \\
\hline \multicolumn{9}{|l|}{2013} \\
\hline Ames-S & 182 & 166 & 172 & 0.32 & 0.20 & 0.18 & 0.629 & 0.360 \\
\hline Ames-C & 88 & 83 & 88 & 0.21 & 0.15 & 0.14 & 0.962 & 0.727 \\
\hline Kanawha & 197 & 187 & 196 & $0.61 a$ & $0.41 b$ & $0.40 \mathrm{~b}$ & 0.697 & 0.020 \\
\hline \multicolumn{9}{|l|}{ Crop rotation } \\
\hline Mean SC & 168 & 171 & 175 & $0.37 a$ & $0.33 a$ & $0.28 b$ & 0.389 & 0.012 \\
\hline Mean CC & 94 & 95 & 96 & 0.19 & 0.17 & 0.14 & 0.951 & 0.304 \\
\hline
\end{tabular}

Notes: $\mathrm{SC}=$ corn after soybean. $\mathrm{CC}=$ continuous corn. Spring-N rates used for comparison was $150 \mathrm{lb} \mathrm{N} \mathrm{ac}^{-1}$ for SC and $200 \mathrm{lb} \mathrm{N}$ ac ${ }^{-1}$ for CC. Letters indicate significant differences within a row at the $p \leq 0.10$ level.

the VRN ${ }^{\mathrm{R}}$ strategy was $168 \mathrm{~kg} \mathrm{~N} \mathrm{ha}^{-1}(150$ $\left.\mathrm{lb} \mathrm{N} \mathrm{ac}{ }^{-1}\right)$ in SC and $224 \mathrm{~kg} \mathrm{~N} \mathrm{ha}^{-1}(200 \mathrm{lb}$ $\mathrm{N} \mathrm{ac}{ }^{-1}$ ) in CC. The spring- $\mathrm{N}$ base rates for the VRN ${ }^{\mathrm{S}}$ strategy were $84 \mathrm{~kg} \mathrm{~N} \mathrm{ha}^{-1}(75 \mathrm{lb}$ $\left.\mathrm{N} \mathrm{ac}^{-1}\right)$ in SC and $112 \mathrm{~kg} \mathrm{~N} \mathrm{ha}^{-1}(100 \mathrm{lb} \mathrm{N}$ $\mathrm{ac}^{-1}$ ) in $\mathrm{CC}$. There was no minimum $\mathrm{N}$ rate for VRN ${ }^{\mathrm{R}}$, but not less than $84 \mathrm{~kg} \mathrm{~N} \mathrm{ha}^{-1}(75$ lb N ac ${ }^{-1}$ ) for SC or $112 \mathrm{~kg} \mathrm{~N} \mathrm{ha}^{-1}(100 \mathrm{lb} \mathrm{N}$ $\mathrm{ac}^{-1}$ ) for CC with VRN ${ }^{\mathrm{s}}$. Because the VRN $\mathrm{N}^{\mathrm{s}}$ and $\mathrm{VRN}^{\mathrm{R}}$ rates were above the EONR for most site-years (one exception was the Nashua 2013 site-year where yield responded to the highest spring- $\mathrm{N}$ rate applied), the $\mathrm{AE}$ values would be reduced compared to an optimal $\mathrm{N}$ rate. Grain yield was statistically the same between the spring- $\mathrm{N}$ and the two VRN strategies at all site-years, except for Nashua 2013 where yield increased at spring- $\mathrm{N}$ rates greater than the 84 and 168 $\mathrm{kg} \mathrm{N} \mathrm{ha}^{-1}$ (75 and $150 \mathrm{lb} \mathrm{N} \mathrm{ac}^{-1}$ ) comparison rates. At that site-year, grain yield was significantly different across each VRN strategy and spring-N $\left(V_{R} N^{R}>V_{R} N^{S}>\right.$ spring-N), with overall corn yield quite high.

The across site-year mean grain yield for both rotations was the same for spring-N and the two VRN strategies. This indicates the base spring- $\mathrm{N}$ rate in both rotations was an adequate or nearly adequate rate to maximize yield, that more $\mathrm{N}$ applied with either VRN strategy was not needed (only needed at the Nashua 2013 site-year), or response to the V10 growth stage VRN application was poor. Due to the dry growing conditions, a lower base spring- $\mathrm{N}$ rate for the $\mathrm{VRN}^{\mathrm{S}}$ and no requirement in the $84 \mathrm{~kg} \mathrm{~N}$ $\mathrm{ha}^{-1}\left(75 \mathrm{lb} \mathrm{N} \mathrm{ac}^{-1}\right)$ for SC or $112 \mathrm{~kg} \mathrm{~N} \mathrm{ha}^{-1}$ $\left(100 \mathrm{lb} \mathrm{N} \mathrm{ac}^{-1}\right)$ for CC minimum application would have been appropriate. This approach would have minimized over-application and improved the chances for the VRN management to correctly address $\mathrm{N}$ deficiencies. Also, end-users need to gain confidence and be comfortable with a possible reduction in the total amount of $\mathrm{N}$ applied to a corn crop.

The AE was not different between the spring-N base rate and the VRN strategies except for three site-years. The greatest $\mathrm{AE}$ was achieved with the $\mathrm{VRN}^{\mathrm{S}}$ strategy at the Chariton 2012 site-year (despite low corn yields) and the base spring-N AE was greater than with eitherVRN strategy at the Kanawha and Nashua 2013 site-years. Most notably was the high AE at the Nashua 2013 site-year with the spring-N and VRN strategies, which was due to the base rate of 84 and $168 \mathrm{~kg} \mathrm{~N} \mathrm{ha}^{-1}$ (75 and $150 \mathrm{lb} \mathrm{N} \mathrm{ac}^{-1}$ ) being well below the $280 \mathrm{~kg} \mathrm{~N}^{-1}(250 \mathrm{lb}$ $\mathrm{N} \mathrm{ac}{ }^{-1}$ ) rate where yield response was still occurring. The across site-year SC mean AE was statistically the same between spring-N and $V R N^{S}$, and both were higher than the $\mathrm{VRN}^{\mathrm{R}}$. The mean AE for CC was not different between the spring-N and VRN strategies, and the values were low and much lower, respectively, than the SC rotation.

The VRN ${ }^{\mathrm{S}}$ and $\mathrm{VRN}^{\mathrm{R}}$ strategies were designed to demonstrate a simplified method of using canopy sensors for VRN management by either splitting or rescuing $\mathrm{N}$ with two application timings. Delgado et al. (2005) showed site-specific management zones had greater agronomic use efficiencies of $\mathrm{N}$ fertilizer use, even at higher $\mathrm{N}$ rates, where $\mathrm{NO}_{3}^{-}$leaching was highest in the low productivity zones and lowest in high productivity zones. In this study, the designated base spring- $\mathrm{N}$ rates for each strategy and the requirement for a minimum V10 application rate for the $\mathrm{VRN}^{\mathrm{S}}$ strategy limited the potential benefit from variable rate decisions-partially due to the dry conditions experienced. Continuous corn yielded poorly due to the drought stress experienced in this study. Those conditions would also affect potential benefit from VRN applications due to poor synchronization between in-season applied $\mathrm{N}$, crop $\mathrm{N}$ demand, and uptake under water stressed conditions.

\section{Summary and Conclusions}

Variable rate $\mathrm{N}$ management used in this study split $\mathrm{N}$ application so that a corn canopy sensing tool could account for site-year $\mathrm{N}$ variability. However, significant climatic factors (particularly drought conditions) 
occurred during and after VRN application and could not be accounted for by remote sensing at the midvegetative growth stage. The VRN management in conjunction with 0 and $56 \mathrm{~kg} \mathrm{~N} \mathrm{ha}{ }^{-1}\left(50 \mathrm{lb} \mathrm{N}^{-1}\right.$ ) spring-N was most closely aligned with the across site-year spring-N EONR with SC; however no VRN application with $\mathrm{CC}$ aligned well with the mean across site-year EONR. The canopy sensing was not able to detect adequate to excess $\mathrm{N}$ in V10 corn, with the VRN ${ }^{\mathrm{S}}$ and $\mathrm{VRN}^{\mathrm{R}}$ strategies directing more $\mathrm{N}$ than needed. Therefore, algorithm decision-making criteria should incorporate $\mathrm{N}$ fertilizer applications made prior to sensing and VRN applications. Also, full yield response to VRN was not always achieved when zero $\mathrm{N}$ was spring applied, especially in the SC rotation.

There were no corn yield differences between spring- $\mathrm{N}$ and the $\mathrm{VRN}^{\mathrm{S}}$ and $\mathrm{VRN}^{\mathrm{R}}$ strategies in either rotation. Generally, corn yields were low in the 2012 and 2013 years, with corn production in CC especially challenging in the adverse dry growing conditions (yield gap between crop rotation was approximately $4,390 \mathrm{~kg} \mathrm{ha}^{-1}[70$ $\left.\mathrm{bu} \mathrm{ac}^{-1}\right]$ ). For good utilization of intensive $\mathrm{N}$ management, like VRN based on canopy sensing, corn yield potential should be high in order to achieve response to varying applications. Overall, the AE was not high in this study, somewhat related to the growing season conditions and limited yield. Similar to corn yield, the highest $\mathrm{AE}$ was achieved with VRN when $56 \mathrm{~kg} \mathrm{~N} \mathrm{ha}^{-1}\left(50 \mathrm{lb} \mathrm{N} \mathrm{ac}{ }^{-1}\right)$ was spring applied in the $\mathrm{SC}$ rotation. The $\mathrm{AE}$ in $\mathrm{CC}$ was low (compared to the AE of SC) with no improvement with VRN management. The AE with the spring-N and $\mathrm{VRN}^{\mathrm{S}}$ in SC were the same, but the $\mathrm{VRN}^{\mathrm{R}}$ applied more in-season $\mathrm{N}$, which significantly reduced AE. The AE in $\mathrm{CC}$ was the same for both VRN strategies (and much lower than in SC) due to low corn yield.

Crop rotation, springtime $\mathrm{N}$ application rate, sensor calibration technique, and weather during and after in-season canopy sensing should be factors that are integrated for VRN application decisions and are important for successful corn yield response to VRN management. Stopgap measures, such as maximum VRN rates and recognizing crop stresses that are unrelated to $\mathrm{N}$, should be considered so that prescribed $\mathrm{N}$ rates can be better aligned with total corn $\mathrm{N}$ need within each growing season. Results from this study provide important informa- tion on how to translate remote sensing data into improved VRN management strategies and better water quality.

\section{Acknowledgements}

This research was funded in part by the regional collaborative project supported by the USDA National Institute of Food and Agriculture (NIFA), Award No. 2011-6800230190, Cropping Systems Coordinated Agricultural Project: Climate Change, Mitigation, and Adaption in Corn-based Cropping Systems.

\section{References}

Abendroth, L.J., R.W. Elmore, M.J. Boyer, and S.K. Marlay. 2011. Corn Growth and Development. PMR 1009. Ames, IA: Iowa State University Extension.

Baker, J.L., D.R. Timmons, R.S. Kanwar, and F.B. Amos Jr. 1995. Optimum time of nitrogen application to improve nitrogen use-efficiency and reduce leaching. Integrated Farm Management Demonstration Program Comprehensive Report, IFM 16, p. 4.3-4.5. Ames, IA: Iowa State University Extension.

Barker, D.W., and J.E. Sawyer. 2010. Using active canopy sensors to quantify corn nitrogen stress and nitrogen application rate. Agronomy Journal 102:964-971.

Barker, D.W., and J.E. Sawyer. 2012. Using active canopy sensing to adjust nitrogen application rate in corn. Agronomy Journal 104:926-933.

Delgado, J.A., R. Khosla, W.C. Bausch, D.G. Westfall, and D.J. Inman. 2005. Nitrogen fertilizer management based on site-specific management zones reduces potential for nitrate leaching. Journal of Soil and Water Conservation 60(6):402-410.

Doerge,T.A. 2002.Variable-rate nitrogen management creates opportunities and challenges for corn producers. Crop Management doi:10.1094/CM-2002-0905-01-RS.

Fox, R.H., and C.L. Walthall. 2008. Crop monitoring technologies to assess nitrogen status. In Nitrogen in Agricultural Systems, ed. J.S. Schepers and W. Raun, 647670. Soil Science Society of America (SSSA) Monograph 49. Madison, WI: Soil Science Society of America.

Holland, K.H., and J.S. Schepers. 2013. Use of a virtualreference concept to interpret active crop canopy sensor data. Precision Agriculture 14:71-85.

IPNI (International Plant Nutrition Institute). 2013. 4R Plant Nutrition Manual: A Manual for Improving the Management of Plant Nutrition, 1st edition, eds. T.W. Bruulsema, P.E. Fixen, and G.D. Sulewski. Norcross, GA: International Plant Nutrition Institute.

ISU (Iowa State University) Agronomy Extension. 2012. Corn nitrogen rate calculator: Finding the maximum return to $\mathrm{N}$ and most profitable $\mathrm{N}$ rate. Ames, IA: Iowa State University Agronomy Extension. http://extension. agron.iastate.edu/soilfertility/nrate.aspx.

Jaynes, D.B., and T.S. Colvin. 2006. Corn yield and nitrate loss in subsurface drainage for midseason nitrogen fertilizer application. Agronomy Journal 98:1479-1487.
Khosla, R., K. Fleming, J.A. Delgado, T.M. Shaver, and D.G. Westfall. 2002. Use of site-specific management zones to improve nitrogen management for precision agriculture. Journal of Soil and Water Conservation 57(6):513-518.

Killorn, R.J., R.D. Voss, and J.S. Hornstein. 1995. Nitrogen fertilizer management studies, 1987-1991. Integrated Farm Management Demonstration Program Comprehensive Report, 2.3-2.15. Ames, IA: Iowa State University Extension.

Lawrence, J. 2014. Reducing nutrient loss: Science shows what works. SP 435. Ames, IA: Iowa State University Extension.

Mallarino, A.P., J.E. Sawyer, and S.K. Barnhart. 2013. A general guide for crop nutrient and limestone recommendations in Iowa. PM 1688. Ames, IA: Iowa State University Extension.

Randall, G., J.A. Delgado, and J.S. Schepers. 2008. Nitrogen management to protect water resources. In Nitrogen in Agricultural Systems, eds. J.S. Schepers and W. Raun, 911-945. Soil Science Society of America (SSSA) Monograph 49. Madison, WI: SSSA.

Randall, G.W., J.A. Vetsch, and J.R. Huffman. 2003. Corn production on a subsurface-drained mollisol as affected by time of nitrogen application and nitrapyrin. Agronomy Journal 95:1213-1219.

Ruiz Diaz, D.A., J.A. Hawkins, J.E. Sawyer, and J.P. Lundvall. 2008. Evaluation of in-season nitrogen management strategies for corn production. Agronomy Journal 100:1711-1719.

SAS Institute. 2010. The SAS system for Windows. Release 9.1. Cary, NC: SAS Institute.

Sawyer, J., E. Nafziger, G. Randall, L. Bundy, G. Rehm, and B. Joern. 2006. Concepts and rationale for regional nitrogen rate guidelines for corn. PM 2015. Ames, IA: Iowa State University Extension.

Scharf, P.C., J.P. Schmidt, N.R. Kitchen, K.A. Sudduth, S.Y. Hong, J.A. Lory, and J.G. Davis. 2002. Remote sensing for nitrogen management. Journal of Soil and Water Conservation 57(6):518-524.

USDA NRCS (Natural Resources Conservation Service). 2015a. Water Quality Enhancement ActivityPrecision application technology to apply nutrients. WQL11. Washington, DC: USDA NRCS.

USDA NRCS. 2015b. Water Quality Enhancement Activity-Split nitrogen applications, 50\% after crop emergence or pasture green up. WQL07. Washington, DC: USDA NRCS.

USDA NRCS. 2015c. Water Quality Enhancement Activity-Apply enhanced efficiency fertilizer products. WQL32. Washington, DC: USDA NRCS.

USDM (United States Drought Monitor). Tabular Data Archive jointly produced by the National Drought Mitigation Center at the University of Nebraska-Lincoln, USDA, and the National Oceanic and Atmospheric Administration. http://droughtmonitor.unl.edu/. 